\title{
Ribonucleoprotein PTB-Binding 2
}

National Cancer Institute

\section{Source}

National Cancer Institute. Ribonucleoprotein PTB-Binding 2. NCI Thesaurus. Code C134318.

Ribonucleoprotein PTB-binding 2 (691 aa, $74 \mathrm{kDa}$ ) is encoded by the human RAVER2 gene. This protein plays a role in RNA binding and may affect RNA processing. 